\title{
Harvesting and chewing as constraints to forage consumption by the African savanna elephant (Loxodonta africana)
}

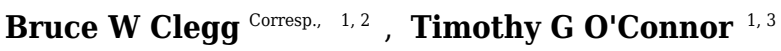 \\ ${ }^{1}$ School of Animal, Plant and Environmental Sciences, University of the Witwatersrand, Johannesburg, South Africa \\ 2 The Malilangwe Trust, Chiredzi, Zimbabwe \\ ${ }^{3}$ Coordinators Unit, South African Earth Observation Network, Pretoria, South Africa \\ Corresponding Author: Bruce W Clegg \\ Email address: bruce@malilangwe.org
}

As a foundation for understanding the diet of African savanna elephants (Loxodonta africana), adult bulls and cows were observed over an annual cycle to determine whether harvesting, chewing and handling times differed across food types and harvesting methods (handling time is defined as the time to harvest, chew and swallow a trunkload of food). Bulls and cows were observed 105 and 26 times respectively (94 and 26 individuals), with a total of 64 hours of feeding recorded across 32 vegetation types. Some food types took longer to harvest and chew than others, which may influence intake rate and affect choice of diet. The method used to gather a trunkload of food had a significant effect on harvesting time, with simple foraging actions being comparatively rapid and more difficult tasks taking longer. Handling time was constrained by chewing for bulls, except for the processing of roots from woody plants, which was limited by harvesting. Time to gather a trunkload had a greater influence on handling time for cows compared to bulls. Harvesting and handling times were longer for bulls than cows, with the sexes adopting foraging behaviors that best suited their energy requirements. 
1 Harvesting and chewing as constraints to forage consumption by the African savanna

2 elephant (Loxodonta africana)

3

4 Bruce W. Clegg 1,2,*, Timothy G. O’Connor ${ }^{1,3}$

5

$6{ }^{1}$ School of A.P.E.S., University of the Witwatersrand, Johannesburg, South Africa

$7 \quad 2$ The Malilangwe Trust, Chiredzi, Zimbabwe

$8{ }^{3}$ South African Earth Observation Network, Pretoria, South Africa

9 


\section{ABSTRACT}

As a foundation for understanding the diet of African savanna elephants (Loxodonta africana),

adult bulls and cows were observed over an annual cycle to determine whether harvesting, chewing and handling times differed across food types and harvesting methods (handling time is defined as the time to harvest, chew and swallow a trunkload of food). Bulls and cows were observed 105 and 26 times respectively (94 and 26 individuals), with a total of 64 hours of feeding recorded across 32 vegetation types. Some food types took longer to harvest and chew than others, which may influence intake rate and affect choice of diet. The method used to gather a trunkload of food had a significant effect on harvesting time, with simple foraging actions being comparatively rapid and more difficult tasks taking longer. Handling time was constrained by chewing for bulls, except for the processing of roots from woody plants, which was limited by harvesting. Time to gather a trunkload had a greater influence on handling time for cows compared to bulls. Harvesting and handling times were longer for bulls than cows, with the sexes adopting foraging behaviors that best suited their energy requirements. 


\section{INTRODUCTION}

51

African savanna elephants (Loxodonta africana) utilize a wide variety of forage types, consuming leaves, stems, roots and tubers from herbaceous vegetation (grass and forbs) (Barnes 1982; de Boer et al. 2000; de Longh et al. 2004; Wyatt \& Eltringham 1974), and leaves, twigs, bark, roots, flowers and fruits from woody plants (Field 1971; Guy 1976; Owen-Smith \& Chafota 2012). Although elephants harvest food from a range of plant life forms, it is their conspicuous impact on woodlands that has the greatest potential to cause long-term vegetation change (Lamprey et al. 1967; Laws 1970; Leuthold 1977; Morrison et al. 2016). Extensive conversion of woodlands to shrubland by elephants (Spinage 1994) and the potential associated loss of biodiversity (Cumming et al. 1997; Herremans 1995; Kerley \& Landman 2006) may require management intervention (O'Connor et al. 2007), but any action should be based on an understanding of why elephants choose to utilize woody plants in a destructive manner. Impact on woody vegetation is greatest when harvesting methods such as breaking branches, debarking stems, or toppling, pollarding or uprooting whole plants are used, and less when trunkloads of leaves are stripped without breaking branches (O’Connor et al. 2007). When diet is composed solely of grass and forbs there is no damage to woody plants. Therefore knowledge of the factors that influence choice of diet and mode of harvesting is required before impact on woody vegetation can be understood. involves locating suitable food patches, harvesting trunkloads, and chewing and swallowing 
70

71

72

73

74

75

76

77

harvested material. The time to complete these individual tasks may vary across forage types, potentially causing differences in the rate at which each forage type can be ingested. This in turn may influence diet and habitat selection because elephants possibly seek to maximize their rate of intake of food rich in easily digestible cell solubles (Clegg 2010; O'Connor et al. 2007). Food types that can be located, harvested and chewed quickly should have higher preference than those that take longer to ingest. Determinants of searching time (time to locate a food patch) have been investigated for elephants (Clegg \& O'Connor unpublished data), but the potential for differences in harvesting and chewing times across the range of forage types consumed is yet to be explored. Adult females have half the body mass of adult males (Owen-Smith 1988) and this may cause differences in the strength and capacity available for harvesting and chewing fibrous food types. Consequently, the possibility that gender influences time to harvest and chew food is also explored in this study.

Early foraging models assumed that harvesting and chewing by herbivores were mutually exclusive processes (Farnsworth \& Illius 1996; Farnsworth \& Illius 1998; Spalinger \& Hobbs 1992). However, harvesting and chewing have been shown to overlap for both cattle (Laca et al. 1994) and giraffe (Ginnett \& Demment 1995). This is also true for elephants because the trunk allows harvesting to take place while food is being chewed (Clegg 2010). This overlap means that handling time (time to harvest, chew and swallow a trunkload of food; $H_{t}$ ) is constrained by either harvesting time $\left(P_{t}\right)$ or chewing time $\left(C_{t}\right)$ depending on which action takes longest (i.e. when $P_{t}>\mathrm{C}_{\mathrm{t}}, H_{t}=P_{t}$, but when $H_{\mathrm{t}}>P_{t}, H_{t}=\mathrm{C}_{\mathrm{t}}$ ) (Clegg 2010). Therefore harvesting methods that involve laborious, time-consuming actions may considerably lower the rate of food intake even if trunkloads are rapidly chewed and swallowed. This study focused on foraging within a food 
92 patch. Movement between patches necessitates the inclusion of searching time as an additional 93 constraint, and this is dealt with elsewhere using a more complete foraging model (Clegg 2010).

94

95

The aim of this study was to determine whether harvesting, chewing and handling time differ across food types as a foundation for understanding diet choice of elephants. The following specific questions were addressed. (1) Do some forage types take longer to harvest and chew than others? (2) Does the method used to gather a trunkload affect harvesting time? (3) Is handling time constrained by harvesting or chewing? (4) Does gender influence handling time?

\section{MATERIALS \& METHODS}

\section{Study area}

The study was conducted in the semi-arid savanna of Malilangwe Wildlife Reserve (50 000 ha) in south-eastern Zimbabwe $\left(20^{\circ} 58^{\prime}-21^{\circ} 15^{\prime} \mathrm{S}, 31^{\circ} 47^{\prime}-32^{\circ} 01^{\prime} \mathrm{E}\right)$. Permission to carry out the research was granted by The Malilangwe Trust. Ethical approval was not required because elephants were simply observed in the wild and not interfered with in any way. The reserve has a hot wet season from November to March, a cool dry season from March to August, and a hot dry season from September to October. Mean annual rainfall is $557 \mathrm{~mm}(n=64 ; C V=34.2 \%)$, with approximately $84 \%$ falling in the hot wet season. Rainfall during the year of study was $716 \mathrm{~mm}$. The average minimum and maximum monthly temperatures range from $13.4{ }^{\circ} \mathrm{C}$ (July) to $23.7{ }^{\circ} \mathrm{C}$ (December), and $23.2^{\circ} \mathrm{C}$ (June) to $33.9^{\circ} \mathrm{C}$ (November) respectively (Clegg 2010). Frost is rare. Thirty-eight vegetation types, from open grassland to dry deciduous forest, have been identified on seven geological types, with soils ranging from $90 \%$ sand to $41 \%$ clay (Clegg \& O'Connor 2012). 


\section{Data collection \& analysis}

116 Harvesting time $\left(P_{t}\right)$ and handling time $\left(H_{t}\right)$ were estimated for different food types by observing

117 elephants feeding between April 2002 and March 2003. Chewing time $\left(C_{t}\right)$ was not estimated

118 directly, but because of the potential for complete overlap between harvesting and chewing, when

$119 H_{t}>P_{t}$, it was assumed that $H_{t}=C_{t}$. Observations were made in as many vegetation types and

120 times of day as possible. No observations were made at night. Once elephants were located, a focal

121 individual was chosen. Random selection was impossible because of the dictates of wind direction,

122 availability of cover for an undetected approach and the presence of other elephants, and therefore

123 selection was restricted to the most accessible adult (approximately $>30$ years old). The sex of the

124 focal animal was recorded and characteristics such as tusk length, shape and size, and torn ears

125 were noted to ensure recognition during sampling. Observations were made on foot or from a

126 vehicle for the larger family groups at a distance of 20 to $50 \mathrm{~m}$ using binoculars. The time at the

127 start of the feeding record was noted. The following was recorded for each trunkload by talking at

128 the instant of each foraging action into a head-set microphone attached to a dictaphone that was

129 running continuously: (1) when the elephant began to harvest a trunkload, (2) harvesting method,

130 (3) forage type, (4) plant species, and (5) when the trunkload was placed in the mouth. The point

131 at which the elephant finished chewing a mouthful was assumed to take place the instant before

132 the next trunkload was placed in the mouth. It was also noted when the elephant left a patch of

133 food and started to feed in a new patch. The elephant was deemed to have left a woody patch if it

134 abandoned the shrub or tree it had been feeding on or an herbaceous patch if it walked more than

135 two paces without feeding from the herbaceous layer. If the focal elephant disappeared from view,

136 recording was stopped. Recording continued when the elephant reappeared. If it became obvious

137 that the elephant was walking to water as opposed to actively feeding, or if feeding was disturbed 
138 in any other way, the observation was abandoned. The route and distance travelled during the 139 observation period was recorded by saving a track on a Global Positioning System. The dictaphone 140 recordings were transferred to a computer where they were analyzed using Winamp® (a digital 141 audio player) and Microsoft Excel. Because the dictaphone was running continuously, the 142 recording preserved the intervals between feeding actions. Consequently when recordings were 143 played using Winamp ${ }^{\circledR}$ the time at the start and end of each feeding action could be read to the 144 nearest second off the digital timer. These times were transferred to Excel spreadsheets that were 145 used to construct data sets for $P_{t}$ and $H_{t}$ that included forage type, harvesting method, vegetation 146 type, month, and elephant gender and ID for each trunkload. $H_{t}$ was calculated as the interval 147 between consecutive mouthfuls of a food type gathered from a single patch using the same method 148 of harvesting.

Many combinations of forage type and harvesting method had insufficient observations for analysis and therefore a single categorical variable called "Ftype" that included the nine most common combinations (pluck green grass, pluck and shake mixed grass, pluck green forbs, strip green leaves from woody plants, pluck leaves and twigs from woody plants, chew off bark from canopy branches, remove bark from the main stem of trees, break off root from woody plants, dig and break off root from woody plants) was constructed. To account for spatial, temporal, and within subject non-independence of observations we used the glmer function of the lme4 package of R (Bates et al. 2015) to create generalized linear mixed-effects models (GLMM) with harvesting 157 or handling time as the dependent variable, and forage type (factor with 9 levels) and sex (factor with 2 levels) as fixed effects. Vegetation type (spatial non-independence), month (temporal nonindependence), and elephant ID (within subject non-independence) were used as crossed, uncorrelated, random intercept effects. Models failed to converge when slope was included in the 
161 structure of random effects. Therefore only random intercepts were considered. Distributions of

162 harvesting and handling times were right skewed so models were specified with the gamma

163 distribution and log link to achieve homoscedasticity of residuals. The interaction between main

164 effects was not included because data were missing for some forage type and gender combinations.

165 Models with all possible groupings of random intercept effects were compared by assessing

166 goodness of fit using Akaike (AIC) and Bayesian (BIC) information criteria acquired using the

167 AIC (R Core Team 2016) and BIC (Pinheiro et al. 2016) functions of R respectively. The Anova

168 (Fox \& Weisberg 2011) and anova (R Core Team 2016) functions, and lsmeans package (Lenth

169 2016) of $\mathrm{R}$ were then run on the outputs of the best models to determine the significance of the

170 fixed effects and calculate the least squares means of harvesting and handling time (and $95 \%$

171 confidence intervals) for the different forage type and gender combinations. The lsmeans package

172 was used to conduct pairwise comparisons of the least squares means across forage types using

173 Tukey's adjustment. Within forage types, we tested for a significant difference between harvesting

174 and handling times by calculating the $95 \%$ confidence interval of the difference (intervals that

175 included zero were not significant). We used the Pythagorean Theorem to calculate the standard

176 error of the difference because estimates of $P_{t}$ and $H_{t}$ were derived from separate models. The Z-

177 statistic, with a value of 1.96 , was used because the sample size was greater than 30 . Labfit

178 software (Silva \& Silva 2011) was used to determine the function that best fit the relationship

179 between mean handling time and the frequency of observations for each forage type.

\section{RESULTS}

Adult bulls and cows were observed 105 and 26 times respectively (96 and 26 individuals), with

183 a total of 64 hours of feeding recorded across 32 vegetation types. Cows were observed less 
184 frequently than bulls because they tended to associate in large groups (up to 80 individuals) and

185 were therefore more difficult to approach on foot. A total of 109 plant species were consumed.

Food types utilized were whole grass plants, grass inflorescences (only observed for cows), grass roots, whole forb plants, leaves and twigs of woody plants, bark from canopy branches of trees and shrubs, bark from the main stems of trees, bark from roots of trees and shrubs, roots of trees and shrubs, tubers (caudices), flowers and fruits. Often a trunkload was composed of more than one food type e.g. leaves and twigs or leaves and fruits.

Harvesting methods varied within and across food types. Grass plants were plucked by wrapping the trunk around the above-ground portions of a tuft and pulling to uproot the plant. If soil was attached to the roots or a significant amount of senescent leaf material was present, this was removed by thrashing the tuft against the chest or front leg. Most often the entire grass plant was consumed, but when the base of tillers was particularly robust, only the upper portion of the tuft was eaten, the roots and bases of the tillers being discarded. Grass roots were harvested in the same way except the above ground portions of the plant were discarded and only the roots eaten. Grass inflorescences were gathered by wrapping the trunk around a number of culms and pulling. Forbs with an erect growth form were plucked in a similar way to grass tufts, with the entire plant being consumed. Forbs with a creeping or climbing growth habit were gathered by extracting a long length, bundling it in the trunk, and then inserting the bundle into the mouth. Leaves of woody plants were either stripped or plucked. Stripping was most commonly done by wrapping the trunk around a leafy branch and then pulling the trunk along the length of the branch. Leaves were also stripped by loosely grasping a leafy branch in the mouth and then allowing the branch to run through the mouth while moving away from the plant. Stripping often resulted in a substantial amount of twigs being included in the trunkload. Leaves were plucked using the projections at the 
207 end of the trunk. Plucking appeared to result in fewer twigs being included in the trunkload 208 compared to stripping, but the mass of the trunkload was potentially reduced. Leaves and twigs

209 were harvested by wrapping the trunk around a slender branch and then bending the branch until

210 it snapped. The entire branch was then consumed. For woody species with bark of high tensile

211 strength (e.g. Acacia tortilis), leaves and twigs were harvested by grasping the end of a branch in

212 the mouth and then drawing the branch taught across the end of a tusk until it snapped. Preference

213 for this harvesting technique was indicated by the development of a marked groove a few

214 centimeters back from the tip of the working tusk. Often an additional action such as breaking 215 down a branch or felling the tree was required before a trunkload of leaves or leaves and twigs 216 could be harvested. Bark was harvested from the canopy branches of shrubs and trees by snapping 217 off a branch (approximately $2 \mathrm{~cm}$ in diameter) with the trunk, placing it in the mouth and then 218 chewing off the bark along the length of the branch. Bull elephants harvested bark from the main 219 stems of trees by gouging and prizing out sections using their tusks. Once gouging had created a 220 piece of bark that could be grasped by the trunk with sufficient purchase, the bark was stripped away by pulling upwards. This was only possible for tree species with bark of an adequate tensile strength. Bulls most frequently employed this technique. Cows preferred to either snap the main stem or locate a tree whose main stem had been snapped and then strip off small pieces of bark by 224 pulling on the torn, jagged edges of bark that were created when the stem was snapped. Cows 225 frequently employed this technique when harvesting bark from the main stems of small (main 226 stems of approximately $<15 \mathrm{~cm}$ diameter) Colophospermum mopane trees. Roots were harvested 227 by excavating with the feet, uprooting shrubs by plucking with the trunk, pushing over trees or by 228 grasping exposed roots with the trunk and pulling to lift long sections out of the soil. Tubers (e.g. those of Jatropha spp.) were particularly sought after by cows after rain in areas with sandy soil. 
230 A unique method was used to harvest tubers. First the tuber would be partially excavated by

231 ploughing backwards and forwards through the soil with a foot. The moist soil after rain facilitated

232 digging because the soil did not slide back into the hole. Once part of the tuber was exposed the

233 elephant would kneel down and impale the tuber with a tusk. The elephant would then stand up

234 and remove the tuber from the tusk using the trunk and place it in its mouth. Fruits where either

235 plucked from the plant or picked up from the ground after the tree had been shaken to dislodge the

236 fruits. When gathering small fruits from the ground (e.g. pods from Acacia tortilis) the fruits were

237 swept into a pile, which was then ladled into the mouth using the trunk.

238 Data used for the GLMM's had fewer observations for harvesting than handling (Table 1)

239 because when elephants were feeding from a dense sward it was difficult to record precisely when

240 harvesting began. The AIC and BIC scores indicated that the best model for harvesting included

241 elephant ID and month as random effects, while that for handling also included vegetation type as

242 an additional random effect (Table 2). Analysis of variance showed that both forage type and sex

243 had a significant influence on harvesting and handling times (Table 3).

244 Harvesting times were short for trunkloads of green grass, forbs and leaves from woody

245 plants (5.8-9.5 s for bulls, 4.3-7.1 s for cows); intermediate for trunkloads of mixed grass, leaves

246 and twigs, and bark from canopy branches (11.4-18.3 s for bulls, 8.6-13.7 s for cows); and long

247 for trunkloads of roots from woody plants and main stem bark (22.8-62.1 s for bulls, 17.1-46.7 s

248 for cows) (Fig. 1). Additional harvesting actions, such as shaking a tuft of grass to remove

249 senescent material, significantly $(P<0.05)$ increased harvesting time relative to instances when

250 additional actions were not required. Handling times were short for trunkloads of leaves from

251 woody plants, forbs and green grass (13.5-14.7 $\mathrm{s}$ for bulls, 8.7-9.4 $\mathrm{s}$ for cows); intermediate for

252 leaves and twigs, roots from woody plants and mixed grass (21.7-25.7 $\mathrm{s}$ for bulls, 14.0-16.5 $\mathrm{s}$ for 
253 cows); and long for canopy bark, main stem bark and roots from woody plants that had to be

254 excavated before being broken off (48.9-64.4 s for bulls, 31.4-41.4 s for cows) (Fig. 2). Cows had

255 shorter harvesting and handling times $(P<0.05)$ than bulls.

256 Handling time was constrained by chewing for bulls, except for the processing of roots

257 from woody plants which was limited by harvesting (Fig. 3). Time to gather a trunkload had a

258 greater influence on handling for cows than bulls, with 4 out of the 9 food types being constrained

259 by harvesting as opposed only 2 for bulls (Fig. 4). For both bulls and cows, trunkloads of food

260 types with the shortest handling times were recorded most frequently (Fig. 5).

\section{DISCUSSION}

263 Time to harvest and chew food has been shown to influence the intake rate of many herbivore

264 species (for examples see Ginnett \& Demment 1997; Illius et al. 2002; Laca et al. 1994; Pastor et 265 al. 1999), but to the best of our knowledge, this is the first published study to investigate this for 266 African savanna elephants (Loxodonta africana). Harvesting times for elephants were longer than 267 those recorded for other large mammalian herbivores. For example, elephant bulls took 5.8-62.1 s 268 to gather a trunkload, while elk (Cervus canadensis) and wood bison (Bison bison athabascae) 269 took $0.7 \mathrm{~s}$ and $0.5 \mathrm{~s}$ respectively (Bergman et al. 2000; Gross et al. 1993). This was also the case 270 for handling time, with elephant bulls taking 13.5-64.4 s to harvest and chew a mouthful and horses 271 (Equus caballus) and roe deer (Capreolus capreolus) taking 1.2-3 s and $2.1 \mathrm{~s}$ respectively 272 (Fleurance et al. 2009; Illius et al. 2002).

Large differences in harvesting and handling times were apparent across food types. For example, bulls took three times longer to process trunkloads of main stem bark than trunkloads of leaves from woody plants. Differences in handling times are possibly more conspicuous for 
276 elephants than other herbivores because an unusually broad assortment of forage types is utilized

277 and a particularly diverse array of harvesting methods is employed. Variation in handling time

278 might affect the rate of intake when feeding on different food types, which may in turn influence

279 food preferences and choice of diet (Clegg 2010; O'Connor et al. 2007). Elephants have a fast rate

280 of passage of ingesta (Eltringham 1982). To capitalize on this they should prefer food types that

281 can be harvested and chewed rapidly compared to those that can only be processed more slowly

282 (Clegg 2010; O'Connor et al. 2007). Our observations supported this hypothesis because when all

283 food types were available during the rainy season elephants ate predominantly green grass, forbs

284 and leaves from woody plants (Clegg 2010), which are the food types that can be harvested and

285 chewed most rapidly. Only when these had senesced during the dry season did elephants feed more

286 on bark and roots, which required more laborious harvesting methods and took longer to process.

287 This seasonal change in diet has been frequently reported in the literature (Cerling et al. 2004;

288 Owen-Smith 1988). It is important to recognize that handling time is one of many potential

289 constraints to food intake. Other factors such as search time (Spalinger \& Hobbs 1992), bite mass

290 (Shipley 2007), protein and energy content of forage (Shrader et al. 2012), presence of secondary

291 metabolites and tannin-binding proteins (Owen-Smith \& Chafota 2012; Schmitt et al. 2016;

292 Shrader et al. 2012), and distance from a source of drinking water (Harris et al. 2008) also influence

293 the relative profitability of the available food types. These are, however, considered beyond the

294 scope of this study and will be addressed elsewhere.

295 Mode of harvesting had a significant effect on harvesting time. Harvesting was shorter

296 when trunkloads could be gathered by simply plucking or stripping and longer when additional

297 actions were necessary. For example, it took bulls almost twice as long to harvest grass tufts with

298 a mixture of green and dry leaves compared to those with only green leaves. This was because an 
299 additional action of thrashing the plucked tuft against the chest or front leg to remove senescent 300 material was necessary before the trunkload could be ingested. Similarly, it took twice as long to 301 harvest a trunkload of roots from woody plants if they had to be dug up first compared to situations 302 where they were already exposed. This is consistent with the hypothesis that hedging of the tree 303 layer by elephants facilitates foraging because it allows food to be harvested more rapidly and with 304 less energy expenditure (Smallie \& O'Connor 2000).

305 Food types that could be harvested rapidly were eaten most frequently and therefore handling time was most often constrained by chewing. Under these circumstances intake rate can 307 be increased by selecting non-fibrous plant species and parts that can be rapidly chewed. This may partially explain why elephants prefer soft, broad-leaved grasses (e.g. Panicum maximum), climbing forbs that don't invest heavily in structural material, and leaves with a high specific area $\left(\mathrm{cm}^{2} \mathrm{~g}^{-1}\right)$ (Clegg 2010; O'Connor et al. 2007). When rapidly harvestable food types (generally those from the herbaceous layer) are not available, handling becomes constrained by harvesting. This generally leads to increased levels of impact to woody vegetation because the additional actions required to harvest food are often destructive.

The longer handling times for bulls compared to cows were unexpected because the greater strength (body size) of bulls should allow them to harvest and chew food more rapidly. However, bulls extract larger trunkloads than cows and when this is taken into account, bulls do indeed 317 process a greater mass of food per unit time, despite their longer handling times (Clegg 2010). Harvesting methods such as pollarding or uprooting trees and using tusks to prize bark from main stems require considerable strength. Our observations suggest that these foraging techniques are largely the domain of adult bulls, presumably because their body size affords them the necessary

321 strength. Cows appear to have fewer harvesting options available to them. This is supported by the 
322 observation that cows were often seen moving rapidly to a tree that had been felled by a bull,

323 presumably to take advantage of a forage source that would otherwise have been inaccessible. This

324 suggests that impact to woody vegetation should be more closely correlated to the density of adult

325 bulls as opposed to that of the total population (Croze 1974; Guy 1976; Midgley et al. 2005). Cows

326 compensated for their apparent lack of strength by adopting different harvesting methods to bulls.

327 For example, they often extracted main stem bark by first snapping the trunks of small mopane

328 trees and then stripping short lengths of inner bark from the jagged edge of the breaks. Bulls were

329 not observed using this technique. Cows appeared to adopt a strategy of harvesting small

330 trunkloads that allowed for rapid harvesting and chewing. This gave a sense of urgency to their

331 feeding behavior. Bulls on the other hand appeared to be focused on larger trunkloads that took

332 longer to harvest and chew. This difference in foraging behavior is presumably driven by the two-

333 fold difference in body size that causes cows to have a greater energy requirement per unit body

334 mass and bulls to have a greater absolute energy requirement per unit time (O'Connor et al. 2007).

335

336

337

338 CONCLUSION

339 Some forage types took longer to harvest and chew than others, with both gender and the method 340 of gathering food affecting harvesting and handling times. Handling time was mostly constrained

341 by chewing for both sexes, but harvesting did limit processing of some food types, especially for 342 cows. The above differences may cause variation in the rate at which forage types can be ingested, 343 which may in turn influence diet and habitat selection. This however can only be assessed by an 
344 intake model that also includes search time, trunkload mass, number of trunkloads harvested per

345 patch, and the energy content of the forage as additional constraints.

346

347 ACKNOWLEDGEMENTS

348 The authors thank The Malilangwe Trust for initiating the study and Julius Matsuve for assisting 349 with data collection.

350

351

352

353

354

355

356

357

358

359

360

361

362

363

364

365

366

\section{REFERENCES}

Barnes RFW. 1982. Elephant feeding behaviour in Ruaha National Park, Tanzania. African Journal of Ecology 20:123-136.

Bates D, Maechler M, Bolker B, and Walker S. 2015. Fitting linear mixed-effects models using lme4. Journal of Statistical Software 67:48.

Bergman CM, Fryxell JM, and Gates CC. 2000. The effect of tissue complexity and sward height on the functional response of Wood Bison. Functional Ecology 14:69-77.

Cerling TE, Passey BH, Ayliffe LK, Cook CS, Ehleringer JR, Harris JM, Dhida MB, and Kasiki SM. 2004. Orphans' tales: seasonal dietary changes in elephants from Tsavo National Park, Kenya. Palaeogeography, Palaeoclimatology, Palaeoecology 206:367-376.

Clegg BW. 2010. Habitat and diet selection by the African elephant at the landscape level: a functional integration of multi-scale foraging processes. Ph.D. Thesis. University of the Witwatersrand.

Clegg BW, and O'Connor TG. 2012. The vegetation of Malilangwe Wildlife Reserve, southeastern Zimbabwe. African Journal of Range \& Forage Science 29:109-131. 
367 Croze H. 1974. The Seronera bull problem I. The elephants. East African Wildlife Journal 12:1$368 \quad 27$.

369 Cumming DHM, Fenton MB, Rautenbach IL, Taylor RD, Cumming GS, Cumming MS, Dunlop

370

371

372

373

374

375

376

377

378 JM, Ford AG, Hovorka MD, Johnston DS, Kalcounis M, Mahlangu Z, and Portfors CVR. 1997. Elephants, woodlands and biodiversity in southern Africa. South African Journal of Science 93:231-236.

de Boer W, Ntumi CP, Correia AU, and Mafuca JM. 2000. Diet and distribution of elephant in the Maputo Elephant Reserve, Mozambique. African Journal of Ecology 38:188-201.

de Longh HH, Tchamba MT, Aarhaug P, and Verhage B. 2004. Impact of dam construction on two elephant populations in northern Cameroon. Pachyderm 36:30-43.

Eltringham SK. 1982. Elephants. Dorset: Poole.

Farnsworth KD, and Illius AW. 1996. Large grazers back in the fold: generalizing the prey model to incorporate mammalian herbivores. Functional Ecology 10:678-680.

Farnsworth KD, and Illius AW. 1998. Optimal diet choice for large herbivores: an extended contingency model. Ecology 12:74-81.

Field CR. 1971. Elephant ecology in the Queen Elizabeth National Park, Uganda. East African Wildlife Journal 9:99-123.

Fleurance G, Fritz H, Duncan P, and Gordon IJ. 2009. Instantaneous intake in horses of different body sizes: influence of sward biomass and fibrousness. Applied Animal Behaviour Science 117:84-92.

Fox J, and Weisberg S. 2011. An $\{R\}$ companion to applied regression. Thousand Oakes, CA: Sage. http://socserv.socsci.mcmaster.ca/jfox/Books/Companion. 
389 Ginnett TF, and Demment MW. 1995. The functional response of herbivores: analysis and test of 390 a simple mechanistic model. Functional Ecology 9:376-384.

391 Ginnett TF, and Demment MW. 1997. Sex differences in giraffe foraging behaviour at two 392 spatial scales. Oecologia 110:291-300.

393 Gross JE, Shipley LA, Hobbs NT, Spalinger DE, and Wunder BA. 1993. Functional response of 394 herbivores in food-concentrated patches: tests of a mechanistic model. Ecology 74:778395 786. Rhodesia. South African Journal of Wildlife Research 6:55-63.

Harris GM, Russell GJ, van Aarde RI, and Pimm SL. 2008. Rules of habitat use by elephants Loxodonta africana in southern Africa: insights for regional management. Oryx 42:66-75.

Herremans M. 1995. Effects of woodland modification by African elephant Loxodonta africana 401 on bird diversity in northern Botswana. Ecography 18:440-454.

Illius AW, Duncan P, Richard C, and Mesochina P. 2002. Mechanisms of functional response and resource exploitation in browsing roe deer. Journal of Animal Ecology 71:723-734.

Kerley GIH, and Landman M. 2006. The impacts of elephants on biodiversity in the Eastern Cape Subtropical Thickets. South African Journal of Science 102:395-402.

Laca EA, Ungar ED, and Demment MW. 1994. Mechanisms of handling time and intake rate of 407 a large mammalian grazer. Applied Animal Behaviour Science 39:3-19. Park by elephants. East African Wildlife Journal 5:150-167. 15. 
412 Lenth RV. 2016. Least-squares means: the R package lsmeans. Journal of Statistical Software 413 69:33.

414 Leuthold W. 1977. Changes in tree populations of Tsavo East National Park, Kenya. East 415 African Wildlife Journal 15:61-69.

416 Midgley JJ, Balfour D, and Kerley GI. 2005. Why do elephants damage savanna trees? South 417 African Journal of Science 101:213-215.

418 Morrison TA, Holdo RM, and Anderson TM. 2016. Elephant damage, not fire or rainfall, 419 explains mortality of overstorey trees in Serengeti. Journal of Ecology 104:104-113.

420 O'Connor TG, Goodman PS, and Clegg BW. 2007. A functional hypothesis of the threat of local extirpation of woody plant species by elephant in Africa. Biological Conservation 136:329-345.

Owen-Smith, and Chafota J. 2012. Selective feeding by a megaherbivore, the African elephant (Loxodonta africana). Journal of Mammalogy 93:698-705.

Owen-Smith RN. 1988. Megaherbivores: the influence of very large body size on ecology. Cambridge: Cambridge University Press.

Pastor J, Standke K, Farnsworth KD, Moen R, and Cohen Y. 1999. Further development of the

Pinheiro J, Bates D, Debroy S, Sarkar D, and R Core Team. 2016. _nlme: linear and nonlinear mixed effects models. R package version 3.1-125. http://CRAN.Rproject.org $/$ package $=$ nlme $>$.

R Core Team. 2016. A language and environment for statistical computing. R Foundation for Statistical Computing. Vienna, Austria. https://www.R-project.org/. 
435 Schmitt MH, Ward D, and Shrader AM. 2016. Incorporating secondary metabolites, tannin-

436

437

438

439

440

441

442

443

444

445

446

447

448

449

450

451

452

453 binding proteins, and diet breadth into carrying-capacity models for African elephants. Ecological Modelling 332:8-18.

Shipely LA. 2007. The influence of bite size on foraging at larger spatial and temporal scales by mammalian herbivores. Oikos 116:1964-1974.

Shrader AM, Bell C, Bertolli L, and Ward D. 2012. Forest or the trees: At what scale do elephants make foraging decisions? Acta Oecologia 42:3-10.

Silva WP, and Silva CMDPS. 2011. LAB Fit Curve Fitting Software (Nonlinear Regression and Treatment of Data Program). V 7.2.48. www.labfit.net.

Smallie JJ, and O'Connor TG. 2000. Elephant utilization of Colophospermum mopane: possible benefits of hedging. African Journal of Ecology 38:352-359.

Spalinger DE, and Hobbs NT. 1992. Mechanisms of foraging in mammalian herbivores: new models of functional response. The American Naturalist 140:326-348.

Spinage CA. 1994. Elephants. London: Poyser, T. \& Poyser.

Styles CV, and Skinner JD. 2000. The influence of large mammalian herbivores on growth form and utilization of mopane trees, Colophospermum mopane, in Botswana's Northern Tuli Game Reserve. East African Wild Life Society 38:95-101.

Wyatt JR, and Eltringham SK. 1974. The daily activity of the elephant in the Rwenzori National Park, Uganda. East African Wildlife Journal 12:273-289. 
Figure 1 (on next page)

Predicted harvesting times (least squares means) for adult bulls and cows across the commonly utilized forage types.

The compact letter display depicts the results of pairwise comparisons conducted using Tukey's post hoc test. Harvesting times were not significantly different $(P>0.05)$ for forage/gender combinations with letters in common. Bars represent $95 \%$ confidence intervals (back transformed from log scale). 


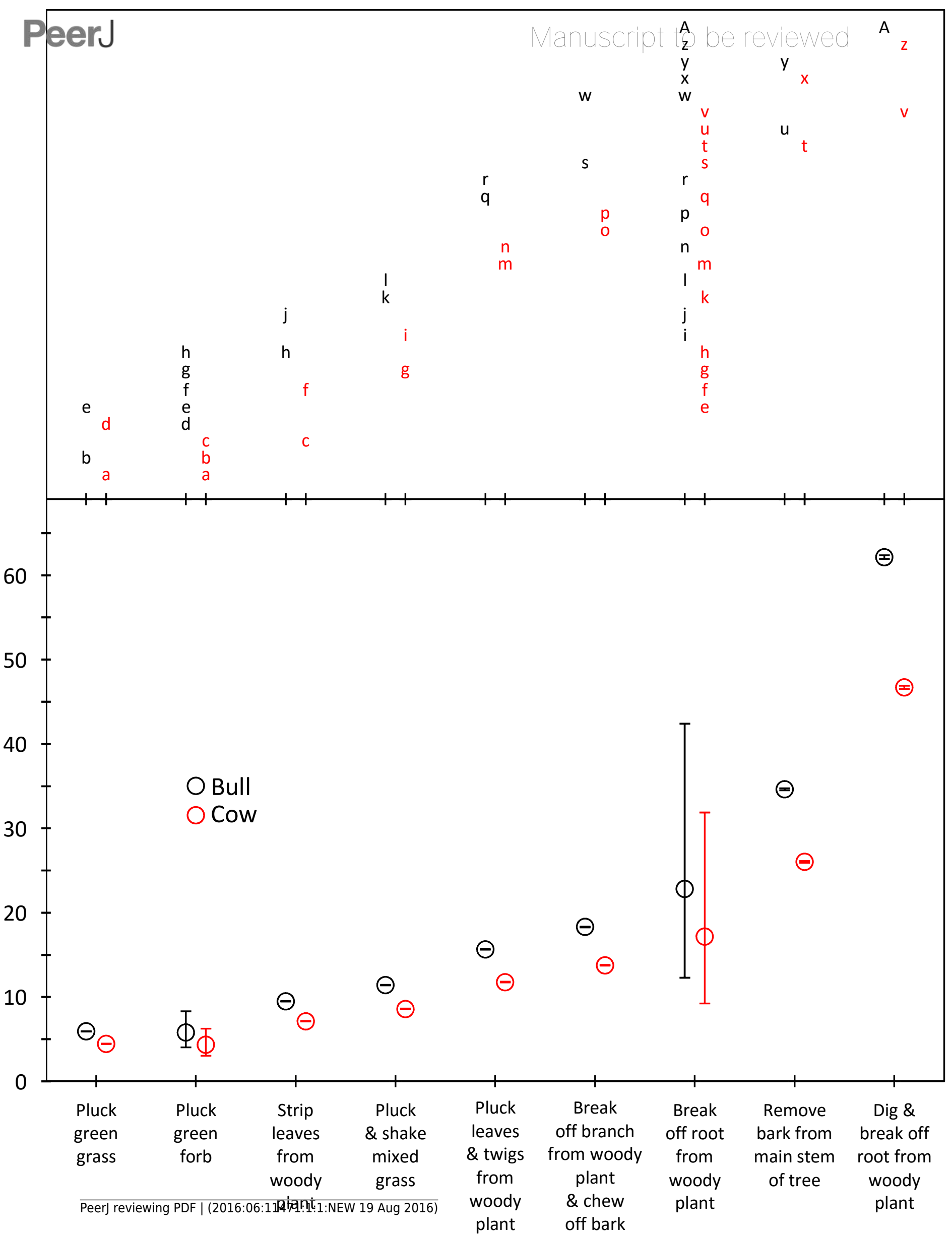




\section{Figure 2 (on next page)}

Predicted handling times (least squares means) for adult bulls and cows across the commonly utilized forage types.

The compact letter display depicts the results of pairwise comparisons conducted using Tukey's post hoc test. Handling times were not significantly different $(P>0.05)$ for forage/gender combinations with letters in common. Bars represent $95 \%$ confidence intervals (back transformed from log scale). 
m

k

m

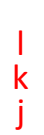

g

e

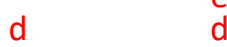

c

d

d

c

a a

80
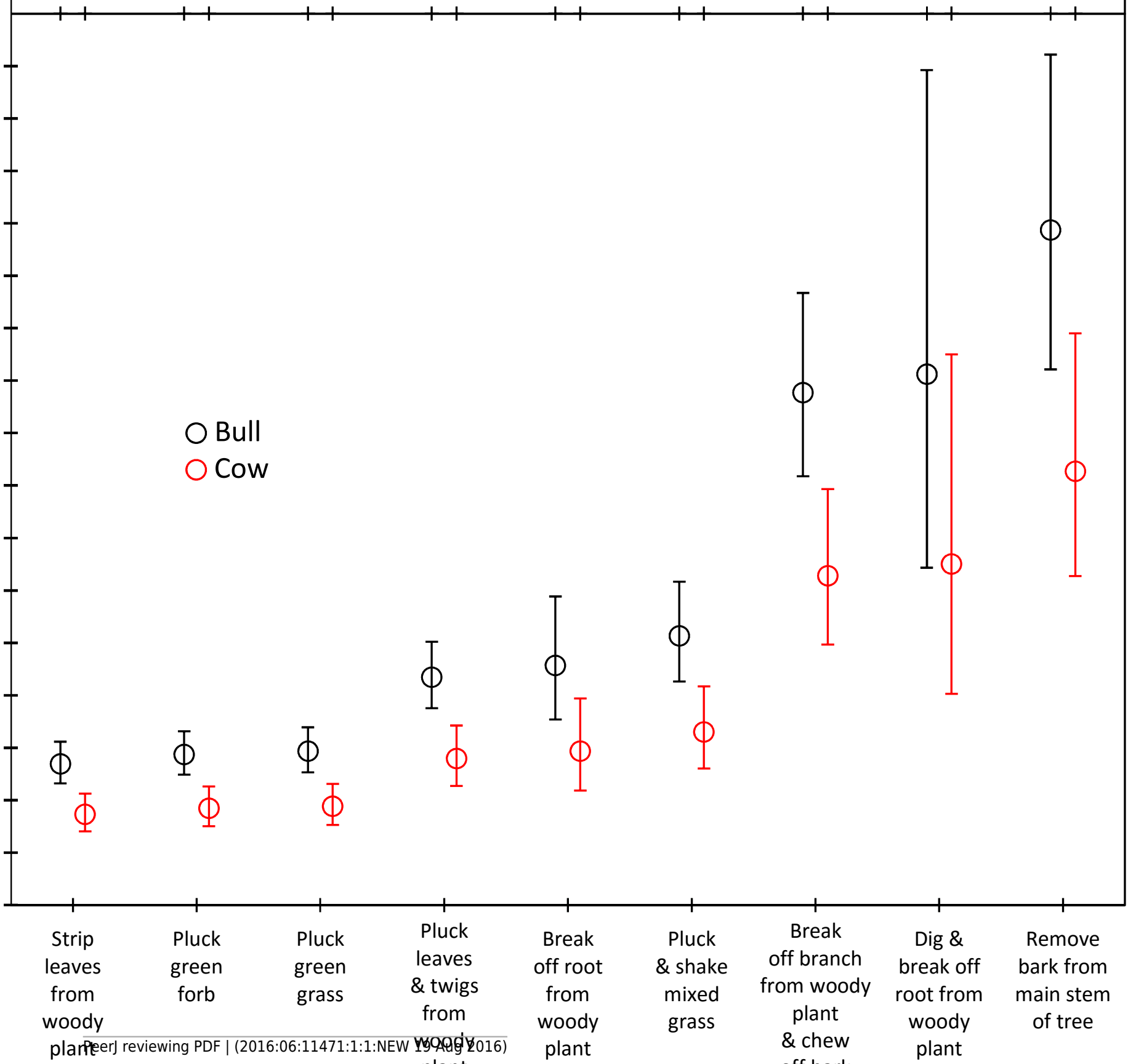

O Bull

Cow

${ }_{30}^{40}$

$\Phi$

$10-\Phi$

$\Phi$

$\oint$

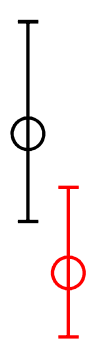

$\Phi$

$\varnothing$

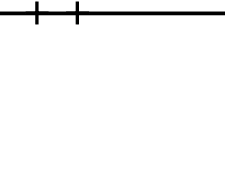


Figure 3 (on next page)

Comparison of harvesting $\left(P_{t}\right)$ and handling times $\left(H_{t}\right)$ for adult bulls for the commonly utilized forage types.

Bars represent $95 \%$ confidence intervals (back transformed from log scale). The significance of the difference between harvesting and handling times was tested for each forage type by calculating the $95 \%$ confidence interval of the difference (intervals that included zero were not significant). Handling was assumed to be constrained by chewing when $H_{t}>P_{t}$. and by harvesting when $H_{t}=P_{t}$. 


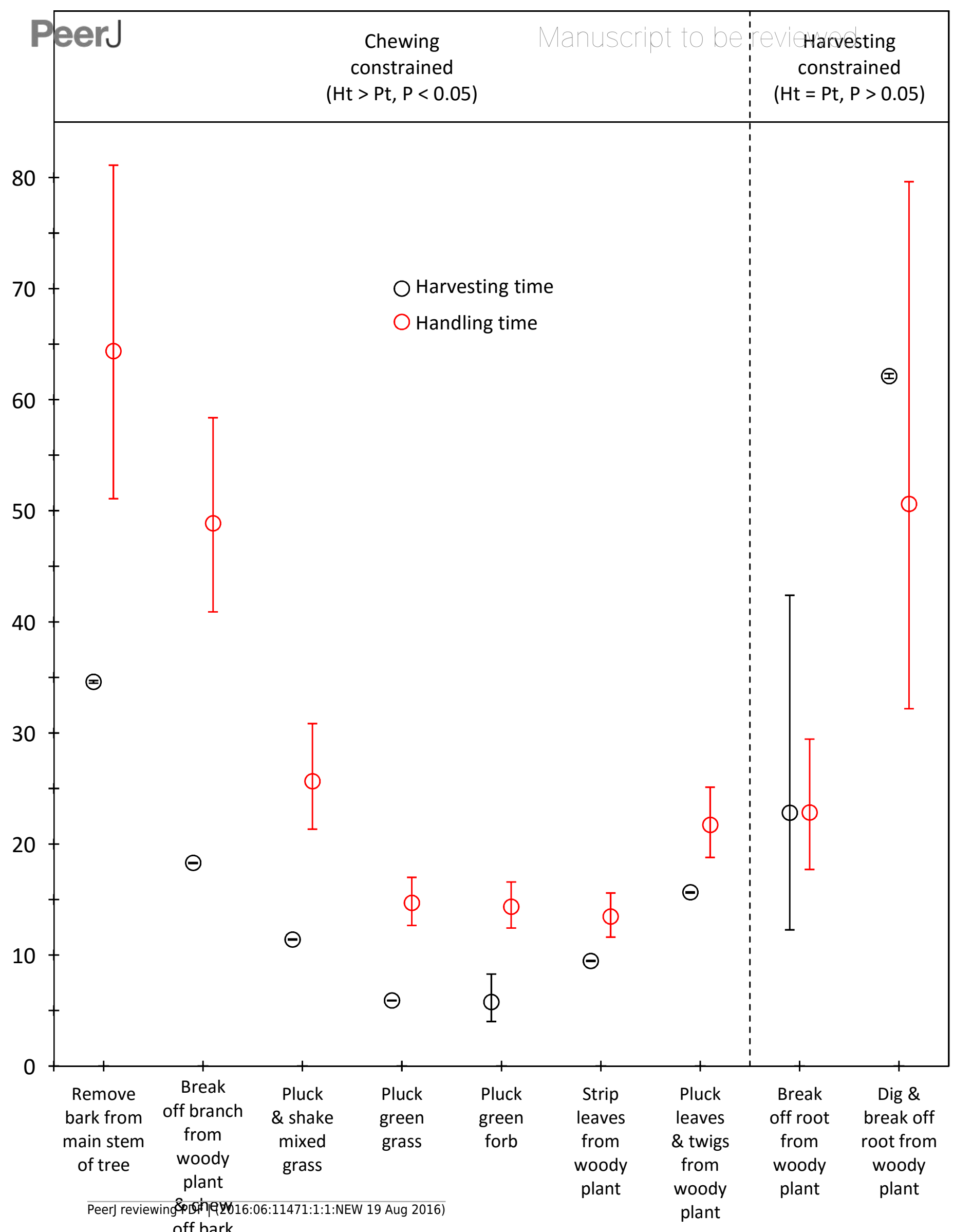


Figure 4 (on next page)

Comparison of harvesting $\left(P_{t}\right)$ and handling times $\left(H_{t}\right)$ for adult cows for the commonly utilized forage types.

Bars represent $95 \%$ confidence intervals (back transformed from log scale). The significance of the difference between harvesting and handling times was tested for each forage type by calculating the $95 \%$ confidence interval of the difference (intervals that included zero were not significant $(P>0.05))$. Handling was assumed to be constrained by chewing when $H_{t}>$ $P_{\mathrm{t}}$. and by harvesting when $H_{t}=P_{t}$. 


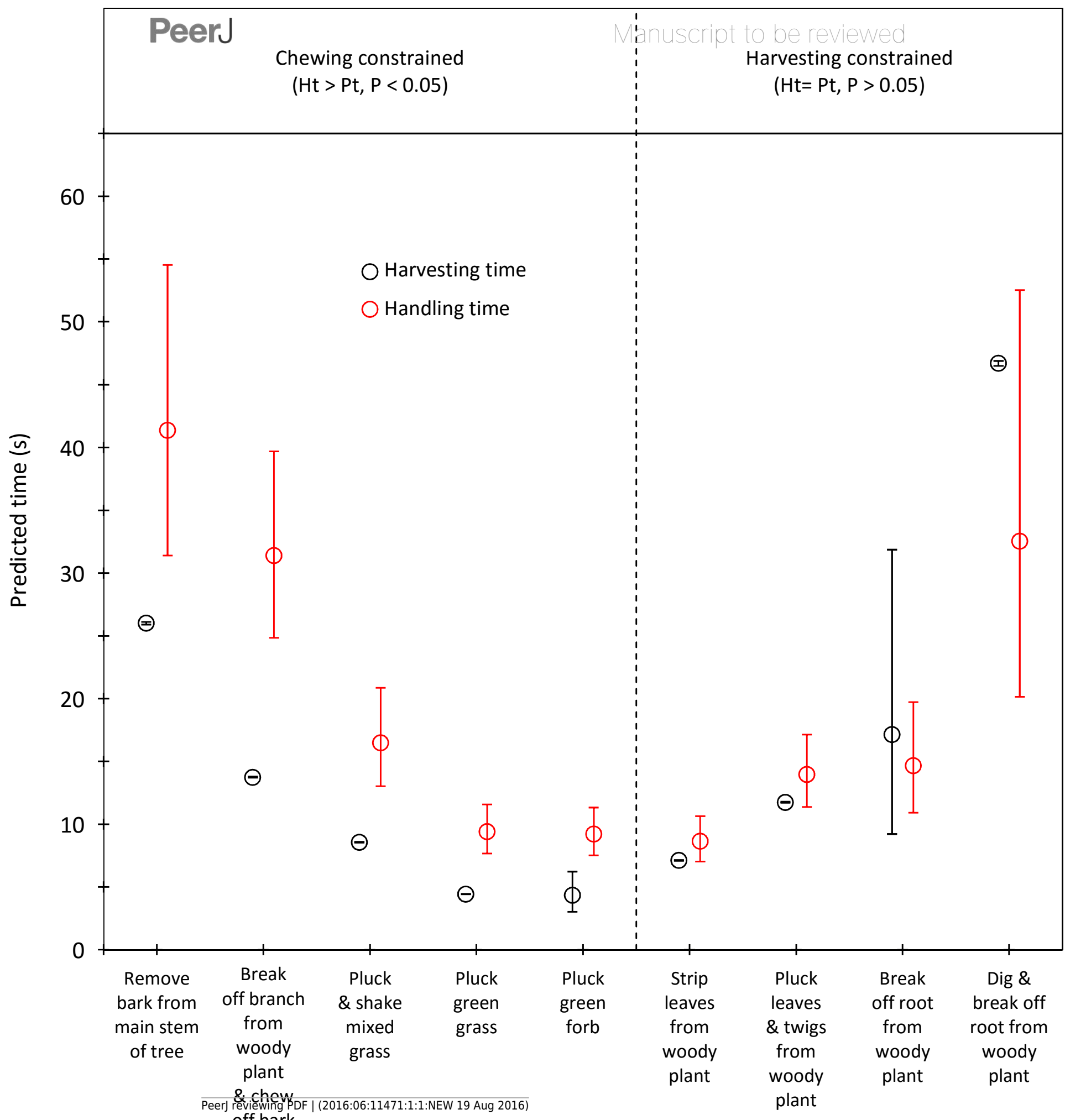




\section{Figure 5 (on next page)}

Relationship between handling time and percent of total trunkloads recorded.

The relationship for bulls (0) was best represented by a second order hyperbola (solid line, $Y=a / x^{2}$, where $\mathrm{a}=2332.246, P<0.001$, adj. $\left.R^{2}=0.729\right)$ and for cows $(O)$ by a first order hyperbola (dashed line, $Y=a / x$, where $a=179.374, P<0.002$, adj. $R^{2}=0.475$ ). 


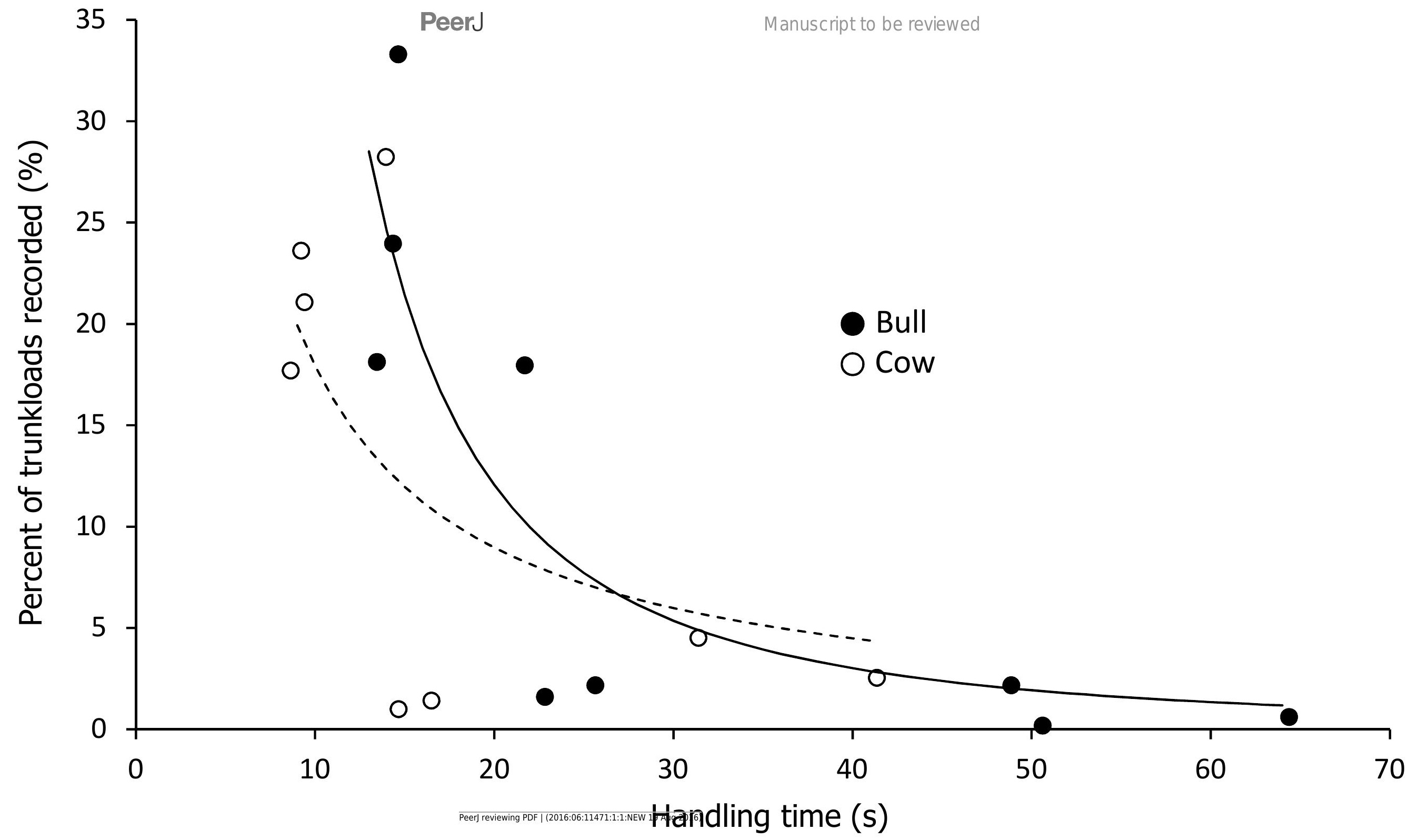




\section{Table $\mathbf{1}$ (on next page)}

Observations per combination of fixed effects used for modelling harvesting and handling times 


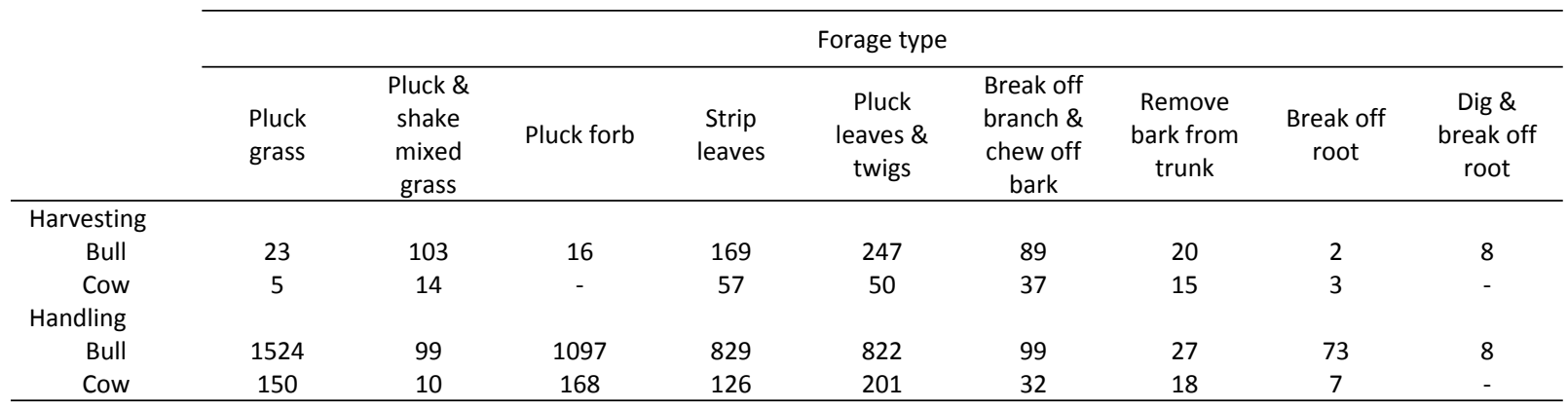

1 


\section{Table 2 (on next page)}

Results of the best GLMM's for harvesting and handling time.

The intercept, estimate (log scale) of the effect of breaking off a canopy branch and chewing off the bark, is a baseline against which the other fixed effects were compared. Forage types with positive estimates took longer to harvest or process than the baseline, and those with negative estimates took less time than the baseline. Negative estimates for sex indicate that cows had shorter harvesting and handling times than bulls 


\begin{tabular}{|c|c|c|c|c|}
\hline \multicolumn{5}{|c|}{ Harvesting time $\sim$ Forage type + Sex $+(1 \mid$ Month $)+(1 \mid$ Elephant ID $)$} \\
\hline Fixed effects & Estimate & Std. Err. & $\mathrm{t}$ value & $\operatorname{Pr}(>|z|)$ \\
\hline \multicolumn{5}{|l|}{ Forage type } \\
\hline Intercept (break off branch \& chew off bark) & 2.906 & 0.001 & 2345.8 & $<0.001$ \\
\hline Pluck forb & -1.153 & 0.184 & -6.3 & $<0.001$ \\
\hline Pluck grass & -1.129 & 0.001 & -910.6 & $<0.001$ \\
\hline Pluck \& shake mixed grass & -0.472 & 0.001 & -369.0 & $<0.001$ \\
\hline Pluck leaves \& twigs & -0.156 & 0.001 & -126.2 & $<0.001$ \\
\hline Strip leaves & -0.658 & 0.001 & -530.6 & $<0.001$ \\
\hline Remove bark from trunk & 0.638 & 0.001 & 514.7 & $<0.001$ \\
\hline Break off root & 0.221 & 0.316 & 0.7 & 0.485 \\
\hline Dig \& break off root & -0.286 & 0.001 & 955.3 & $<0.001$ \\
\hline \multicolumn{5}{|l|}{ Sex } \\
\hline Cow & -0.286 & 0.001 & -230.3 & $<0.001$ \\
\hline Random effects & Variance & Std. Dev. & & \\
\hline Elephant ID & 0.088 & 0.296 & & \\
\hline Month & 0.001 & 0.01 & & \\
\hline \multicolumn{5}{|c|}{ Handling time $\sim$ Forage type + Sex $+(1 \mid$ Vegetation type $)+(1 \mid$ Month $)+(1 \mid$ Elephant ID $)$} \\
\hline Fixed effects & Estimate & Std. Err. & $\mathrm{t}$ value & $\operatorname{Pr}(>|z|)$ \\
\hline \multicolumn{5}{|l|}{ Forage type } \\
\hline Intercept (break off branch \& chew off bark) & 3.889 & 0.091 & 42.85 & $<0.001$ \\
\hline Pluck forb & -1.225 & 0.066 & -18.65 & $<0.001$ \\
\hline Pluck grass & -1.204 & 0.070 & -17.18 & $<0.001$ \\
\hline Pluck \& shake mixed grass & -0.644 & 0.091 & -7.06 & $<0.001$ \\
\hline Pluck leaves \& twigs & -0.811 & 0.070 & -11.65 & $<0.001$ \\
\hline Strip leaves & -1.289 & 0.071 & -18.07 & $<0.001$ \\
\hline Remove bark from trunk & 0.276 & 0.116 & 2.37 & 0.018 \\
\hline Break off root & -0.761 & 0.138 & -5.49 & $<0.001$ \\
\hline Dig \& break off root & 0.035 & 0.236 & 0.15 & 0.881 \\
\hline \multicolumn{5}{|l|}{ Sex } \\
\hline Cow & -0.442 & 0.098 & -4.50 & $<0.001$ \\
\hline Random effects & Variance & Std. Dev. & & \\
\hline Elephant ID & 0.057 & 0.238 & & \\
\hline Vegetation type & 0.025 & 0.16 & & \\
\hline Month & 0.004 & 0.066 & & \\
\hline
\end{tabular}




\section{Table 3 (on next page)}

Analysis of variance tables for the best GLMM's for harvesting and handling times 


\begin{tabular}{lcccccc}
\hline & Df. & Sum Sq. & Mean Sq. & F value & Chisq. & $\operatorname{Pr}$ (>chisq.) \\
\hline Harvesting time & & & & & & \\
$\quad$ Forage type & 8 & 84.45 & 10.56 & 24.05 & 2322278.0 & $<0.001$ \\
Sex & 1 & 2.78 & 2.78 & 6.33 & 53050.0 & $<0.001$ \\
Handling time & & & & & & \\
$\quad$ Forage type & 8 & 251.30 & 31.41 & 97.49 & 882.4 & $<0.001$ \\
Sex & 1 & 11.96 & 11.96 & 37.12 & 20.3 & $<0.001$ \\
\hline
\end{tabular}

1 